\title{
2014's legionnaires' disease outbreak in portugal - an intensive care, single-center. 29 patient case series
}

\author{
B Oliveira, D Nora*, T Carvalho, AM Araujo, L Valente, P Gomes, J Gonçalves-Pereira \\ From ESICM LIVES 2015 \\ Berlin, Germany. 3-7 October 2015
}

\section{Introduction}

Legionnaires' disease, a form of severe pneumonia caused by a Gram negative aerobic intracellular bacteria, was first recognised during an American Legion convention in Philadelphia in July, 1976 [1].

The second largest outbreak of Legionnaires' disease ever registered, encompassing 334 microbiologically documented cases was identified between 7 and 30 of November 2014 in Vila Franca de Xira, Portugal [2] (more than three times the usual annually reported incidence of the disease in the whole country). We report our case series of 29 critically ill patients with Legionella pneumonia admitted to the Hospital Vila Franca de Xira intensive care unit (ICU), located at the epicentre of the outbreak.

\section{Objectives}

To report the epidemiology, clinical features, outcome, treatment strategies, complications and lessons learned during the Legionnaires' disease outbreak in an ICU setting.

\section{Methods}

Prospective collection of clinical and epidemiological data of patients admitted with microbiologically documented Legionella pneumonia to the ICU. This data collection was started at the first day of the outbreak, after admission of 5 consecutive patients with the disease.

\section{Results}

During the outbreak 334 patients with pneumonia were admitted through the emergency room and all either had a positive urinary antigen, culture or serology for
Legionella. As much as 29 of the most severe patients were admitted to Hospital Vila Franca de Xira ICU. The main cause of admission was respiratory failure (97\%), although more than half also presented renal or even multi-organic failure.

Survivors had a median ICU length of stay of 4.48 days (Interquartile range (IQR) 3-5) and a median hospital length of stay of 14.2 days (IQR 11-18.5). Overall there were four deaths in the ICU, a case fatality of $13.7 \%$. Mean duration of hospital stay before death was 2.25 days. Patients were treated with high dose levofloxacin (1.5g/day). Non-responders also received rifampicin after 72 hours [3]. One patient experienced seizures and levofloxacin was replaced by azithromycin. A surprisingly high new incidence of atrial fibrillation (20\% of patients), which was not previously described, was noted.

\section{Conclusions}

A Legionella pneumonia outbreak was registered in November 2014 in Portugal. Several patients needed intensive care mostly for respiratory failure. A new-onset atrial fibrillation was the most common complication noted.

Published: 1 October 2015

\section{References}

1. Fraser DW, et al: Legionnaires' disease: description of an epidemic of pneumonia. N Engl J Med 1977, 297(22):1189-97, Dec 1.

2. Shivaji $\mathrm{T}$, et al: A large community outbreak of Legionnaires' disease in Vila Franca de Xira, Portugal, October to November 2014. Euro Surveill 2014, 19(50).

3. Rello J, et al: Community-acquired Legionella Pneumonia in the intensive care unit: Impact on survival of combined antibiotic therapy. Med Intensiva 2013, 37(5):320-6, Jun-Jul. Epub 2012 Jul 31. 
doi:10.1186/2197-425X-3-S1-A353

Cite this article as: Oliveira et al: 2014's legionnaires' disease outbreak in portugal - an intensive care, single-center. 29 patient case series. Intensive Care Medicine Experimental 2015 3(Suppl 1):A353.

\section{Submit your manuscript to a SpringerOpen ${ }^{\circ}$ journal and benefit from:}

- Convenient online submission

- Rigorous peer review

- Immediate publication on acceptance

- Open access: articles freely available online

- High visibility within the field

- Retaining the copyright to your article

Submit your next manuscript at $\gg$ springeropen.com 